\title{
Treating Hypotension in Preterm Neonates With Vasoactive Medications
}

\author{
Chloe Joynt ${ }^{1}$ and Po-Yin Cheung ${ }^{1,2,3 *}$
}

'Department of Pediatrics, University of Alberta, Edmonton, AB, Canada, ${ }^{2}$ Department of Pharmacology and Surgery, University of Alberta, Edmonton, $A B$, Canada, ${ }^{3}$ Centre for the Studies of Asphyxia and Resuscitation, Edmonton, $A B$, Canada

Preterm neonates often have hypotension which may be due to various etiologies. While it is controversial to define hypotension in preterm neonates, various vasoactive medications are commonly used to provide the cardiovascular support to improve the blood pressure, cardiac output, or to treat shock. However, the literature on the systemic and regional hemodynamic effects of these antihypotensive medications in neonates is deficient and incomplete, and cautious translation of findings from other clinical populations and animal studies is required. Based on a literature search on published reports, meta-analytic reviews, and selected abstracts, this review discusses the current available information on pharmacologic actions, clinical effects, and side effects of commonly used antihypotensive medications including dopamine, dobutamine, epinephrine,

OPEN ACCESS

Edited by:

Eugene Dempsey,

University College Cork, Ireland

Reviewed by:

Joseph Ting,

University of British

Columbia, Canada

Arno Van Heijst,

Radboud University Medical

Center, Netherlands

*Correspondence:

Po-Yin Cheung

poyin@ualberta.ca

Specialty section:

This article was submitted

to Neonatology,

a section of the journal

Frontiers in Pediatrics

Received: 10 January 2018

Accepted: 19 March 2018

Published: 13 April 2018

Citation:

Joynt $C$ and Cheung P-Y (2018)

Treating Hypotension in

Preterm Neonates With

Vasoactive Medications.

Front. Pediatr. 6:86.

doi: 10.3389/fped.2018.00086 norepinephrine, vasopressin, and milrinone in preterm neonates.

Keywords: newborn, prematurity, inotropes, catecholamines, blood pressure, hypotension

Antihypotensive treatments are often started in response to a low blood pressure (BP) or signs of low cardiac output (CO) in critically ill neonates. The challenge for clinicians in the neonatal intensive care unit (NICU) is to dissect out the etiology of the hemodynamic changes, decide if the changes are pathologic or transitionally appropriate, and then tailor the treatment regimen for the patient, the condition, and gestation. This process all occurs while being cognizant that a hemodynamic state evolves throughout the chronological age of the neonate and the course of illness and is affected by concurrent treatments, such as ventilation. Studies in Europe, North America, and Australia all highlight that practices are variable across countries and continents with respect to which patient, when and how to treat with cardiotonic drugs (1-6).

A national Canadian database reported that $10 \%$ of neonates of $<29$ weeks had been treated with inotropes on days 1-3 (0-36\% within the 27 NICUs) (1). The treated neonates were less likely to have received antenatal corticosteroids, more likely have a smaller birthweight, a higher SNAPS II, TRIPS score, and need for ventilation, and had a higher mortality and incidence of intraventricular hemorrhage. Recently, a Norwegian population database study indicated that $2.7 \%$ of all NICU patients received inotropes at any point of their NICU stay; 28 and $4.1 \%$ of $<28$ and $<36$ weeks of gestation, respectively, and $13 \%$ of $<1,500 \mathrm{~g}$ infants (2). These numbers are similar to those reported by Lasky et al. in American NICU (7). Multiple inotropes were associated with an increased mortality. Indeed, the use of inotropes was associated with an increased mortality, after adjusting for gender, gestation, and 5-min Apgar.

\section{DEFINING HYPOTENSION}

Given variations in gestation, birthweight, and perinatal states along with the cardiopulmonary transition, it is challenging to provide a robust definition of hypotension. Many practitioners still define hypotension as a mean BP lower than the gestational age of the baby, most likely deferring to its ease 
of use (5). However, BP increases over time after birth, and it is cautious to use this definition past the first days of life. Although it has not been validated in larger studies, BP nomograms may be a promising alternative to help define hypotension, especially for those patients with extremely low BP.

Transitional and neonatal physiology including fetal shunts as well as disease pathology and iatrogenic effects of concurrent treatments can all contribute to the disruption of hemodynamic homeostasis. During the postnatal transition after birth, there are significant changes in the output of both ventricles as well as systemic and pulmonary vascular resistance which contribute to the initial "physiological" decrease in BP. However, little information is available regarding the minimal effective BP and or blood flow for tissue perfusion in this postnatal hemodynamic state. Permissive hypotension becomes a managerial approach when "hypotension" or low BP is noted in neonates, especially the preterm neonates. It is contemporary to adopt a functional definition of hypotension in the context of clinical effects of hypotension using clinico-biochemical markers of tissue hypo-perfusion.

In pathological conditions such as hypoxia and sepsis, poor myocardial contractility and pulmonary hypertension, which can further be aggravated by acidosis, cause hypotension and tissue hypo-perfusion (8). Systemic vasodilation or vasoplegia is often found in sepsis, profound hypoxia, or postoperatively. Sick neonates often have impaired autoregulation or a redistribution of organ blood flow that alters the relationship between BP, CO, and organ perfusion $(9,10)$.

\section{TREATING HYPOTENSION OR NOT}

A systematic review comparing permissive and $\mathrm{BP}$ value-based hypotension therapeutic strategies in the very preterm infant highlighted the paucity of quality data for either therapeutic approach and little published evidence to link hypotension or treatment to short- and long-term outcomes (11). Faust et al. reported that in neonates born at $<32$ weeks and $<1,500 \mathrm{~g}$, inotropic support was associated with intraventricular hemorrhage and hypotension in the first $24 \mathrm{~h}$ and had an increase in mortality (12). Batton et al. further reported motor, language, and cognitive delay at 18-22 months follow-up in a cohort of hypotensive neonates $<27$ weeks who received BP treatments (4). Interestingly, EPIPAGE 2 cohort study for neonates born at $<29$ weeks recently reported that those who received antihypotensive treatment for isolated hypotension in the first $72 \mathrm{~h}$ had a higher survival rate without major morbidity than matched infants without hypotension treatment (13).

Given the paucity of randomized trials of antihypotensive therapeutics and contradictory data from large cohort studies, there is wide variation in therapies using protocolized or clinical, laboratory and/or technology-based approach $(6,14)$. While it still remains common to treat hypotension with a fluid boluses followed by an infusion of antihypotensive medication, fluid bolus administration may not be beneficial and indeed be harmful $(6,15)$. Conversely, in neonates with compromised intravascular volume due to blood or fluid loss, or capillary leak, fluid administration is essential for proper hemodynamic responses and augments effects of inotropes or pressors. Therefore, fluid therapy should be given with meticulous attention to the intravascular fluid balance or measures, especially for those extremely preterm neonates (16).

\section{VASOACTIVE AGENTS}

Burns et al. reported that dopamine was the most commonly used vasoactive agent with a median duration of administration of $46 \mathrm{~h}$ and a median maximum dose of $10 \mu \mathrm{g} / \mathrm{kg} / \mathrm{min}$, followed by epinephrine ( $33 \mathrm{~h}$ and $0.3 \mu \mathrm{g} / \mathrm{kg} / \mathrm{min}$, respectively) and dobutamine (22 $\mathrm{h}$ and $8.3 \mu \mathrm{g} / \mathrm{kg} / \mathrm{min}$, respectively), with the increasing use of milrinone, norepinephrine, and vasopressin (2). Dopamine, dobutamine, epinephrine, and norepinephrine are categorized as catecholamines as their chemical structure contains a catechol and an amine group. These catecholamines stimulate adrenergic (and/or dopaminergic and serotonergic) receptors not only in the sympathetic nervous system at the synapse but also in the cardiomyocytes, vascular smooth muscle cells, and other extravascular parenchymal cells resulting in complex cardiovascular, renal, and endocrine actions (17). However, the expression in cardiovascular adrenoreceptors can be altered by critical illness, extended catecholamine use, relative adrenal insufficiency as well as gestational age and maturity (18). In the failing myocardium, there is a downregulation of $\beta-1$ adrenoreceptors, an uncoupling of $\beta$-2 adrenoreceptors from adenylyl cyclase, and a decreased cAMP production (19).

\section{DOPAMINE}

Dopamine is an endogenous catecholamine precursor of norepinephrine with sympathetic and neuroendocrine properties (Table 1). It directly stimulates dopaminergic and adrenergic receptors or indirectly, usually in the inotropic dose range, stimulates dopamine-2 receptor to release norepinephrine stored in the peripheral sympathetic nerve endings in the myocardium $(17,20-23)$. The latter indirect mechanism renders dopamine a poor choice for long-term inotropic therapy due to the eventual depletion of endogenous stores.

Our evidence in preterm neonates is mostly inferred from animal studies and small clinical trials (24-28). The effects of dopamine at different doses, different gestations, and chronological ages often receive discussion (11). In a preterm population, the dopaminergic receptors expressed in renal, mesenteric, and coronary vascular beds may be activated at very small dosages $(0.5-2 \mu \mathrm{g} / \mathrm{kg} / \mathrm{min})$, in addition to those regulating the tubular ion fluxes (29). Clinical changes in urine output may be dopaminergic in nature or due to increased renal blood flow and perfusion pressure secondary to its cardiovascular effects. In addition, Seri also suggested that the $\alpha-1$ vasopressive effects occur at $2-5 \mu \mathrm{g} /$ $\mathrm{kg} / \mathrm{min}$ and overlap with the $\beta-1$ inotropic effects which may be at $4-10 \mu \mathrm{g} / \mathrm{kg} / \mathrm{min}$ in premature infants (29). In a study of 18 premature infants, a high dose dopamine $(>10 \mu \mathrm{g} / \mathrm{kg} / \mathrm{min})$ had an unpredictable effect on pulmonary arterial pressures and changed the systemic to pulmonary arterial pressures ratio allowing right to left shunting across the ductus arteriosus and potentially aggravating tissue hypoxia $(24,26,30)$. Furthermore, the clearance of dopamine is gestation-dependent and can be markedly decreased in sick neonates $(31,32)$. Dose-responses 
TABLE 1 | Summary of antihypotensive medications in preterm neonates.

\begin{tabular}{|c|c|c|c|c|}
\hline Medication & Suggested dosing ${ }^{a}$ & Predominant mechanism & Potential clinical uses & Potential side effects \\
\hline \multirow[t]{3}{*}{ Dopamine } & $\leq 2 \mu \mathrm{g} / \mathrm{kg} / \mathrm{min}$ & $\begin{array}{l}\text { Dopaminergic receptors } \\
\text { agonism-proposed renotubular } \\
\text { effects, intestinal and coronary } \\
\text { vasodilation. }\end{array}$ & $\begin{array}{l}\text { A vasopressor which increases blood } \\
\text { pressure if the "hypotension" requires } \\
\text { treatment. }\end{array}$ & \multirow{3}{*}{$\begin{array}{l}\text { - Causes tachycardia. } \\
\text { - Aggravates stress to both ventricles } \\
\text { due to increased afterload. } \\
\text { - At } \geq 10 \mu \mathrm{g} / \mathrm{kg} / \mathrm{min} \text {, may cause right } \\
\text { to left ductal shunt. } \\
\text { - Decreased effect in long term as } \\
\text { indirect pathway substrate becomes } \\
\text { depleted. }\end{array}$} \\
\hline & $\geq 5-10 \mu \mathrm{g} / \mathrm{kg} / \mathrm{min}$ & $\begin{array}{l}\beta \text {-1Adrenergic receptors } \\
\text { agonism-mainly chronotropy }\end{array}$ & $\begin{array}{l}\text { - Increases urine output (increased renal } \\
\text { perfusion pressure and/or natriuresis). }\end{array}$ & \\
\hline & $\geq 10 \mu \mathrm{g} / \mathrm{kg} / \mathrm{min}$ & $\begin{array}{l}\alpha \text {-1Adrenergic receptors } \\
\text { agonism-vasoconstriction }\end{array}$ & - Has a modest effect in cardiac output. & \\
\hline \multirow[t]{2}{*}{ Dobutamine } & $\geq 3-15 \mu \mathrm{g} / \mathrm{kg} / \mathrm{min}$ & $\begin{array}{l}\beta \text {-1Adrenergic receptors } \\
\text { agonism-chronotropy and } \\
\text { inotropy }\end{array}$ & $\begin{array}{l}\text { An inotrope which increases cardiac } \\
\text { output without vasoconstriction, } \\
\text { e.g., cardiogenic shock. }\end{array}$ & \multirow{2}{*}{$\begin{array}{l}\text { - Causes tachycardia. } \\
\text { - Avoid in cardiac outflow tract } \\
\text { obstructions, e.g., infants of diabetic } \\
\text { mothers. }\end{array}$} \\
\hline & & $\begin{array}{l}\beta \text {-2 Adrenergic receptors } \\
\text { agonism-peripheral vasodilation }\end{array}$ & $\begin{array}{l}\text { - Has unpredictable effect on blood } \\
\text { pressure. }\end{array}$ & \\
\hline \multirow[t]{2}{*}{ Epinephrine ${ }^{b}$} & $\geq 0.02-0.1 \mu \mathrm{g} / \mathrm{kg} / \mathrm{min}$ & $\begin{array}{l}\beta \text {-1and some } \beta-2 \text { Adrenergic } \\
\text { receptors agonism-chronotropy } \\
\text { and inotropy, with modest } \\
\text { decrease in PVR }\end{array}$ & $\begin{array}{l}\text { An inotrope with vasopressive action, } \\
\text { e.g., hypotension with decreased cardiac } \\
\text { contractile function with or without } \\
\text { vasoplegia, e.g., septic shock, asphyxia. }\end{array}$ & \multirow{2}{*}{$\begin{array}{l}\text { - Causes hyperlactatemia and } \\
\text { hyperglycemia. } \\
\text { - Causes tachycardia. } \\
\text { - May increase myocardial oxidative } \\
\text { stress. } \\
\text { - Use with caution in cardiac outflow } \\
\text { tract obstructions, e.g., infants of } \\
\text { diabetic mothers. }\end{array}$} \\
\hline & $\geq 0.1 \mu \mathrm{g} / \mathrm{kg} / \mathrm{min}$ & $\begin{array}{l}\alpha \text {-1Adrenergic receptors } \\
\text { agonism-vasoconstriction. }\end{array}$ & $\begin{array}{l}\text { - At } 0.02-0.05 \mu \mathrm{g} / \mathrm{kg} / \mathrm{min} \text {, may increase } \\
\text { cardiac output more than SVR. }\end{array}$ & \\
\hline Norepinephrine ${ }^{b}$ & $0.02-0.4 \mu \mathrm{g} / \mathrm{kg} / \mathrm{min}$ & $\begin{array}{l}\alpha-1(>\beta-1>\beta-2) \text { Adrenergic } \\
\text { receptors agonism-potent } \\
\text { vasoconstriction (and mild } \\
\text { inotropy) }\end{array}$ & $\begin{array}{l}\text { A vasopressor which serves as an adjunct } \\
\text { to other catecholamines at low dose. } \\
\text { - Conditions with significant vasoplegia } \\
\text { in refractory sepsis, post-surgical } \\
\text { inflammation, asphyxia. } \\
\text { - May have mild pulmonary vasodilation } \\
\text { effect. }\end{array}$ & $\begin{array}{l}\text { - Tachycardia. } \\
\text { - May affect regional tissue perfusion } \\
\text { due to potent vasoconstriction. }\end{array}$ \\
\hline Vasopressin & $0.0002-0.005 \mathrm{U} / \mathrm{kg} / \mathrm{min}$ & $\begin{array}{l}\mathrm{V}_{1 \mathrm{a}(>\mathrm{V} 2)} \text { receptors } \\
\text { agonism-vasoconstriction. }\end{array}$ & $\begin{array}{l}\text { A vasopressor which increases blood } \\
\text { pressure in catecholamine-resistant } \\
\text { hypotension or shock }\end{array}$ & $\begin{array}{l}\text { - Hyponatremia. } \\
\text { - Transient thrombocytopenia. } \\
\text { - Liver necrosis. } \\
\text { - Limb necrosis. }\end{array}$ \\
\hline Milrinone & $0.25-0.75 \mu \mathrm{g} / \mathrm{kg} / \mathrm{min}$ & $\begin{array}{l}\text { Phosphodiesterase type III } \\
\text { inhibition with increased cAMP } \\
\text { levels -inotropy, lusitropy, } \\
\text { and pulmonary (and possible } \\
\text { systemic) vasodilation. }\end{array}$ & $\begin{array}{l}\text { - An inotrope/luisitrope with mild } \\
\text { pulmonary vasodilation (inodilator), } \\
\text { e.g., pulmonary hypertension with } \\
\text { ventricular dysfunction, post-PDA } \\
\text { ligation. } \\
\text { - Loading do e is not needed while the } \\
\text { onset of action may take } 1-2 \mathrm{~h} \text {. }\end{array}$ & $\begin{array}{l}\text { - Slow onset. } \\
\text { - Tachycardia. } \\
\text { - Hypotension if decreased } \\
\text { intravascular volume or } \\
\text { administration of a loading dose. } \\
\text { - Decreased platelet aggregation. } \\
\text { - Decreased clearance with kidney } \\
\text { dysfunction. }\end{array}$ \\
\hline
\end{tabular}

PVR, pulmonary vascular resistance; SVR, systemic vascular resistance.

${ }^{a}$ There are variations related to birthweight, gestational age, and disease severity with overlaps in dose-responses of specific receptors agonism. At high doses, antihypotensive medications should be used with caution due to risks for adverse effects, in addition to non-selective receptors stimulation.

buse with caution at $>0.2 \mu \mathrm{g} / \mathrm{kg} / \mathrm{min}$. Indeed, $0.2 \mu \mathrm{g} / \mathrm{kg} / \mathrm{min}$ of epinephrine equates to approximately an hourly administration of bolus epinephrine (10 $\mu \mathrm{g} / \mathrm{kg}$ ) during resuscitation.

also vary in neonates with different underlying pathophysiologies, requiring the titration of dosage based on patient effect and not standardized dosing (33).

There are multiple recent reviews or meta-analyses of dopamine use as an antihypotensive agent for premature neonates $(15,34-36)$. A Cochrane review indicated that dopamine has a modest increase in mean or systolic BP, especially in comparison to dobutamine $(\mathrm{NNT}=4.4,95 \%$ CI 2.9-7.7) $(36,37)$. Despite this vasopressive, but not inotropic, effect, there is no difference in short- or long-term morbidities between dopamine- and dobutamine-treated neonates (36). It is controversial regarding the potential effects of dopamine on cerebral autoregulation (38). Of note, high doses may place the ventricle under stress and, as demonstrated in animal models, may potentiate right to left shunting $(37,39)$. Nonetheless, its ubiquitous nature in many hospital pharmacies, quick onset of action, and historical familiarity continue to play a role in the dopamine use in NICU.

\section{DOBUTAMINE}

Dobutamine is a synthetic catecholamine that acts predominantly on $\beta-1$ adrenoreceptors to increase cardiac contractility (Table 1). It may cause tachycardia, thus increasing myocardial oxygen consumption, at higher doses with the potential for mild peripheral vasodilation (40). Dobutamine, however, may have a role in the transition of preterm neonates who have a low $\mathrm{CO}$ and 
an increased systemic vascular resistance such as polycythemia, asphyxia, or severe acidosis.

Dobutamine, when compared to dopamine, may have better CO or SVC flows in hypotensive preterm neonates $(37,41,42)$. Interestingly, dobutamine $(9.1 \pm 1.1 \mu \mathrm{g} / \mathrm{kg} / \mathrm{min})$ improved stroke volume and $\mathrm{CO}$ of preterm neonates within $20 \mathrm{~min}$, whereas increases in flow velocities at the cerebral, mesenteric, and renal arteries were observed 8-10 h later (43). No difference was found in mortality, intraventricular or periventricular hemorrhage, morbidities at term-corrected age, and outcomes at early childhood $(37,43,44)$.

Perhaps, given the comparative studies of dopamine and dobutamine which show that dopamine increases the readily accessible measurement of $\mathrm{BP}$, while dobutamine may increase CO or SVC flows, a measurement often requiring echocardiography, a recent study in the trend of antihypotensive use indicates that dobutamine has decreased from second to fourth most commonly used medication in the treatment of neonatal hypotension (45).

\section{EPINEPHRINE}

Epinephrine is an endogenous catecholamine that acts directly and dose-dependently on $\alpha-1(>0.1 \mu \mathrm{g} / \mathrm{kg} / \mathrm{min})$ and $\alpha-2, \beta-1$ and $\beta-2(0.02-0.1 \mu \mathrm{g} / \mathrm{kg} / \mathrm{min})$ adrenoreceptors, with vasopressive and inotropic actions, respectively (Table 1 ). There may be a modest decrease in pulmonary vascular resistance as well as vasodilation of renal and mesenteric vasculature at low doses. As doses escalate, vasoconstriction can become intense, tachycardia is pronounced, blood flow to the gut and kidneys decreases, and increased oxygen consumption occurs, although there is still some inotropic action and blood flow is increased to the brain and heart (29). This may put additional stress on an already compromised neonatal heart and peripheral tissues. The pediatric vasoactive inotropic score equates $0.1 \mu \mathrm{g} /$ $\mathrm{kg} / \mathrm{min}$ of epinephrine to $10 \mu \mathrm{g} / \mathrm{kg} / \mathrm{min}$ of dopamine (46). Pharmacodynamic studies in a handful of term and preterm neonates post cardiac surgery demonstrated that a lower birthweight is associated with a lower epinephrine clearance and amplitude in the change of heart rate and BP. It is postulated that this is due to the relative immaturity of the neonatal myocardium, which precludes a significant increase in stroke volume and a variation in $\beta-1$ and $\beta-2$ adrenergic receptor density related to age.

Epinephrine at $>0.5 \mu \mathrm{g} / \mathrm{kg} / \mathrm{min}$ causes excessive vasoconstriction and possibly disorganized energy utilization leading to a decreased CO. In addition to hyperglycemia, hyperlactatemia is a known sequelae of epinephrine infusions due to the stimulation of glycogenolysis via the activation of $\beta-2$ adrenergic receptors and anaerobic metabolism with $\alpha$-adrenergic vasoconstriction (47). Furthermore, sarcolemmal rupture and increased cytoplasmic calcium deposits with resulting decreased myocardial compliance were found with prolonged epinephrine infusions in neonatal piglets (48).

Human neonatal literature on epinephrine is scarce and mostly in preterm neonates (49-52). Pellicer et al. compared the effect of dopamine $(2.5-10 \mu \mathrm{g} / \mathrm{kg} / \mathrm{min})$ and epinephrine $(0.125-0.5 \mu \mathrm{g} /$ $\mathrm{kg} / \mathrm{min}$ ) on cerebral hemodynamics measured by near infrared spectroscopy (51). Epinephrine has similar increases in BP, but more in heart rate at the highest dose range, when compared with dopamine. Cerebral blood flow increased significantly in the more preterm neonates ( $<28$ weeks) with epinephrine and in the more mature neonates (28-32 weeks) with dopamine. This study, however, does not provide information regarding $\alpha$ - and $\beta$-adrenergic agonism. Given the limited literature, there are insufficient data to make recommendations for the use of epinephrine in the preterm neonatal population (53).

\section{NOREPINEPHRINE}

Norepinephrine is an endogenous sympathomimetic amine that acts on the vascular and myocardial $\alpha$-1 receptors with a mild to moderate $\beta$-1 adrenoreceptor agonism (Table 1). As the effect on $\beta-2$ adrenoreceptors is minimal, norepinephrine has combined inotropic and peripheral vasoconstrictive effects (54). The clinical literature on norepinephrine use in neonates is predominantly involving refractory shock and demonstrates increased BP, improved oxygenation, and decreased serum lactate within hours of initiation (55). While improved systemic BP may contribute to the improved oxygenation, norepinephrine may also cause pulmonary vasodilation, particularly in neonates with preexisting increases in basal pulmonary vascular tone, as can be found in severe sepsis (56-58).

A pediatric norepinephrine pharmacokinetic and pharmacodynamics study $(0.5-3 \mu \mathrm{g} / \mathrm{kg} / \mathrm{min})$ included 11 neonates and indicated that variabilities were related to weight, age, and severity of illness which was related to the production and clearance of norepinephrine (59). We found two retrospective studies of norepinephrine use in preterm neonates $(n=48,<32$ weeks and $n=30,<34$ weeks) $(60,61)$. Both studies demonstrated improvements in BP and oxygenation parameters within 3-8 h, with variable effect on urine output. Of note, two-thirds of the patients had sepsis with the majority receiving norepinephrine as an adjunctive therapy. In the studies, tachycardia was very common and mortality was high (30 and 46\%, respectively).

Norepinephrine is often used as a second- or a third-line antihypotensive agent. Adapting practices from pediatric and pediatric cardiovascular intensivists, in the presence of severe vasoplegia or right ventricular failure, the addition of norepinephrine $0.02-0.05 \mu \mathrm{g} / \mathrm{kg} / \mathrm{min}$ when epinephrine doses are reaching $>0.1-0.2 \mu \mathrm{g} / \mathrm{kg} / \mathrm{min}$ allows for the de-escalation of epinephrine and its concurrent side effects of lactic academia and hyperglycemia (personal observations). Further, norepinephrine may improve cardiac performance of both ventricles and coronary systolic BP to assist the right ventricle, especially during ventricular stress (62). However, if the ventricles contractility is impaired, caution should be exercised with excessive systemic vasoconstriction which results in increased afterload and myocardial oxygen demand and worsens unsupported ventricular function.

\section{VASOPRESSIN}

In the last decade, there was a growing use of vasopressin in neonates for various conditions including sepsis, catecholamine 
and corticosteroid-resistant shock, hypotension from ventricular outflow tract obstructions, post cardiopulmonary bypass for congenital cardiac surgery, and pulmonary hypertension (63-67). Vasopressin, or arginine vasopressin (AVP), is an endogenous substance with three subtypes that mediates vasoconstriction $\left(\mathrm{V}_{1}\right)$, regulates water reabsorption $\left(\mathrm{V}_{2}\right)$, and has effects on the central nervous system including the release of adrenocorticotrophic hormone $\left(\mathrm{V}_{3}\right)(68,69)$. The vascular effects of vasopressin occur via the $\mathrm{V}_{1 \mathrm{a}}$ and $\mathrm{V}_{2}$ receptors in the cardiovascular system. The $\mathrm{V}_{1 \mathrm{a}}$ and $\mathrm{V}_{2}$ receptors induce vasoconstriction and vasodilation, respectively, with the potent $\mathrm{V} 1$ vasoconstrictive effects predominating when it is used as an exogenous infusion (Table 1) (70). Experimental studies indicate that low-dose AVP causes selective vasodilation in pulmonary, coronary, and cerebral vasculature under hypoxic conditions while causing vasoconstriction in other vascular beds $(71-74)$.

The neonatal use of vasopressin has been predominantly for catecholamine-resistant shock, hypothetically tackling the hypotension via the depletion of endogenous AVP in a critically ill state as well as the vasoplegia unresponsive to catecholamines $(75,76)$. An increase in the mean BP and the ability to decrease inotrope score were not accompanied by an improved survival and an increased end-organ perfusion (77). This is not surprising in this rescue use of vasopressin in the late shock process. A randomized blinded pilot study compared dopamine (5-20 $\mu \mathrm{g} /$ $\mathrm{kg} / \mathrm{min})$ and vasopressin $(0.0002-0.0007 \mu \mathrm{g} / \mathrm{kg} / \mathrm{min})$ as an initial antihypotensive agent and found no difference in the efficacy and time to response in the treatment of 20 neonates of $<30$ weeks gestation with hypotension at $<24 \mathrm{~h}$ (78). Interestingly, the vasopressin-treated group had lower $\mathrm{PaCO}_{2}$ values and less surfactant needed, compared to the dopamine-treated group.

Adverse effects of vasopressin including hyponatremia, transient thrombocytopenia, and liver necrosis have been reported in neonates, with limb necrosis predominantly in terlipressin use $(63,67,79,80)$. Ni et al. recently reported that the vasopressin use (maximum dose of $0.03 \pm 0.016$ units $/ \mathrm{kg} / \mathrm{h}$ ) was not associated with hyponatremia in 21 preterm neonates $(340-1,390 \mathrm{~g}$, 23-32 weeks of gestation) (81). The summative literature acknowledges that there was insufficient evidence to recommend or refute the use of AVP due to a lack of high-quality trials.

\section{MILRINONE}

Milrinone is a bipyridine derivative that is a phosphodiesterase type III inhibitor that increases intracellular cAMP and calcium concentration through the inhibition of cAMP degradation (Table 1) (82). Milrinone increases myocardial contractility through a cyclic AMP-mediated increase in trans-sarcolemmal calcium flux (inotropy). Milronone also allows calcium resequestration into the sarcoplasma reticulum (vasodilation), and improved actin-myosin dissociation during diastole (lusitropy). Possibly due to its site of action distal to the $\beta$ adrenoreceptor, the myocardial contractile response of milrinone seems to be preserved with ongoing use (51).

Milrinone may improve left ventricular function and reduce pulmonary (venous and arterial) hypertension as it increases
cAMP levels in both cardiomyocytes and pulmonary arterial smooth muscle cells (83). Milrinone has been used in neonates predominantly for pulmonary hypertension and low $\mathrm{CO}$ both before and after cardiac surgery but also in preterm neonates at risk for low systemic blood flow (84-91). A randomized controlled trial of milrinone in preterm neonates showed no clear benefit to prevent low SVC flow in the first few days of life (92). A handful of retrospective and case studies of prophylactic milrinone administration to prevent cardiovascular dysfunction after patent ductus arteriosus ligation demonstrated that milrinone might reduce hemodynamic instability during the first 24 h postoperatively $(93,94)$. However, a recent retrospective comparative study did not confirm a significant cardiovascular or long-term clinical benefit (95).

Animal data have questioned the maturity of phosphodiesterase- 3 receptors at birth and the utility of milrinone in the first days of life, but recent data have shown significant changes of $\mathrm{CO}$ with milrinone use as early as $12 \mathrm{~h}$ of age $(88,96)$. Milrinone has a half-life of approximately $4 \mathrm{~h}$ in neonates, thus rendering a slow onset of action $(97,98)$. Giaccone et al. recently found that renal clearance was increased in relation to gestational and chronological age in term neonates (up to 10 days) (99). Therefore, the dosage of milrinone needs to be adjusted in renal impairment, prematurity, or early chronologic age to avoid drug accumulation and thus side effects including thrombocytopenia $(90,91,99)$.

The multifactorial etiologies of hypotension in preterm neonates require a tailored approach to medical cardiovascular support that focus on more than just maintenance of an acceptable BP. Using of targeted neonatal echocardiography, near infrared spectroscopy, and other hemodynamic/perfusion-monitoring technologies may provide important information regarding the responses to antihypotensive medications, in addition to guiding their use in different scenarios (cardiogenic vs vascular) of hypotension $(100,101)$. An increase in BP should not be deemed a treatment success if excessive vasoconstriction is causing further stresses to cardiac workload or organ tissue oxygenation (102). Although there are many attempts to demonstrate that treating hypotension, as opposed to low blood flow or decreased CO, will improve mortality and morbidity, the literature is still not yet conclusive. Despite ongoing clinical use, literature is sparse with very few comparative studies, on the neonatal use of dobutamine, epinephrine, norepinephrine, vasopressin or milrinone or other cardiovascular supportive therapies for hypotension in preterm neonates.

\section{AUTHOR CONTRIBUTIONS}

CJ: conception of the topic, writing the first draft and final edit and approval of the manuscript. P-YC: conception of the topic, editing, and approval of the manuscript.

\section{FUNDING}

$\mathrm{P}-\mathrm{YC}$ is the site principal investigator of the HIP Trial consortium and received funding from European Union Seventh Framework Programme (FPP7/2007-2013) grant no. 260777. 


\section{REFERENCES}

1. Wong J, Shah P, Yoon E, Yee W, Lee S, Dow K. Inotrope use among extremely preterm infants in Canadian Neonatal Intensive Care Units: variation and outcomes. Am J Perinatol (2015) 32:9-14. doi:10.1055/s-0034-1371703

2. Burns ML, Stensvold HJ, Risnes K, Guthe HJ, Astrup H, Nordhov SM, et al. Inotropic therapy in newborns, a population-based national registry study. Pediatr Crit Care Med (2016) 17:948-56. doi:10.1097/PCC.0000000000000898

3. Batton B, Li L, Newman NS, Das A, Watterberg KL, Yoder BA, et al. Use of antihypotensive therapies in extremely preterm infants. Pediatrics (2013) 131:e1865-73. doi:10.1542/peds.2012-2779

4. Batton B, Li L, Newman NS, Das A, Watterberg KL, Yoder BA, et al. Early blood pressure, antihypotensive therapy and outcomes at 18-22 months' corrected age in extremely preterm infants. Arch Dis Child Fetal Neonatal Ed (2016) 101:F201-6. doi:10.1136/archdischild-2015-308899

5. Stranak Z, Semberova J, Barrington K, O’Donnell C, Marlow N, Naulaers G, et al. International survey on diagnosis and management of hypotension in extremely preterm babies. Eur J Pediatr (2014) 173:793-8. doi:10.1007/ s00431-013-2251-9

6. Seghal A, Osborn D, McNamara PJ. Cardiovascular support in preterm infants: a survey of practices in Australia and New Zealand. J Paediatr Child Health (2012) 48:317-23. doi:10.1111/j.1440-1754.2011.02246.x

7. Lasky T, Greenspan J, Ernst FR, Gonzalez L. Dopamine and dobutamine use in preterm or low birthweight neonates in the premier 2008 database. Clin Ther (2011) 33:2082-8. doi:10.1016/j.clinthera.2011.11.001

8. Lister G, Walter TK, Versmold HT, Dallman PR, Rudolph AM. Oxygen delivery in lambs: cardiovascular and hematologic development. Am J Physiol (1979) 237:H668-75

9. Greisen G. Autoregulation of cerebral blood flow in newborn babies. Early Hum Dev (2005) 81:423-8. doi:10.1016/j.earlhumdev.2005.03.005

10. Tsuji M, Saul JP, du Plessis A, Eichenwald E, Sobh J, Crocker R, et al. Cerebral intravascular oxygenation correlates with mean arterial pressure in critically ill premature infants. Pediatrics (2000) 106:625-32. doi:10.1542/peds. 106.4.625

11. Dempsey EM, Barrington KJ. Treating hypotension in the preterm infant: when and with what: a critical and systematic review. JPerinatol (2007) 27:469-78. doi:10.1038/sj.jp.7211774

12. Faust K, Hartel C, Preuss M, Rabe H, Roll C, Emeis M, et al. Short-term outcome of very-low-birthweight infants with arterial hypotension in the first 24 h of life. Arch Dis Child Fetal Neonatal Ed (2015) 100:F388-92. doi:10.1136/ archdischild-2014-306483

13. Durrmeyer X, Marchand-Martin L, Porcher R, Gascoin G, Roze JC, Storme L, et al. Abstention or intervention for isolated hypotension in the first 3 days of life in extremely preterm infants: association with short-term outcomes in the EPIPAGE 2 cohort study. Arch Dis Child Fetal Neonatal Ed (2017) 102:F490-6. doi:10.1136/archdischild-2016-312104

14. Escourrou G, Renesme L, Zana E, Rideau A, Marcoux MO, Lopez E, et al. How to assess hemodynamic status in very preterm newborns in the first week of life? J Perinatol (2017) 37:987-93. doi:10.1038/jp.2017.57

15. Dempsey EM. What should we do about low blood pressure in preterm infants. Neonatology (2017) 111:402-7. doi:10.1159/000460603

16. Piazza AJ. Postasphyxial management of the newborn. Clin Perinatol (1999) 26:749-65.

17. Seri I. Cardiovascular, renal, and endocrine actions of dopamine in neonates and children. J Pediatr (1995) 126:333-44. doi:10.1016/S0022-3476(95)70445-0

18. Seri I, Evans J. Controversies in the diagnosis and management of hypotension in the newborn infant. Curr Opin Pediatr (2001) 12:116-23. doi:10.1097/00008480-200104000-00005

19. Chatterjee K, De Marco T. Role of nonglycoside inotropic agents: indications, ethics and limitations. Med Clin North Am (2003) 87:391-418. doi:10.1016/ S0025-7125(02)00185-2

20. Subhedar NV. Treatment of hypotension in newborns. Semin Neonat (2003) 8:413-23. doi:10.1016/S1084-2756(03)00117-9

21. Engle WD, Leflore JL. Hypotension in the neonate. NeoReviews (2002) 3:e157-62. doi:10.1542/neo.3-8-e157

22. Osborn DA. Diagnosis and treatment of preterm transitional circulatory compromise. Early Hum Dev (2005) 81:413-22. doi:10.1016/j.earlhumdev. 2005.03.009
23. Noori S, Freidlich P, Seri I. Developmentally regulated cardiovascular, renal and neuroendocrine effects of dopamine. NeoReviews (2003) 4:e283-8. doi:10.1542/neo.4-10-e283

24. Barrington KJ, Finer NN, Chan W. A blind, randomized comparison of the circulatory effects of dopamine and epinephrine infusions in the newborn piglet during normoxia and hypoxia. Crit Care Med (1995) 23:740-8. doi:10.1097/00003246-199504000-00024

25. O'Laughlin MP, Fisher DJ, Dreyer WJ, Smith EO. Augmentation of cardiac output with intravenous catecholamines in unanesthetized hypoxemic newborn lambs. Pediatr Res (1987) 22:667-74. doi:10.1203/00006450-198712000-00011

26. Cheung PY, Barrington KJ. The effects of dopamine and epinephrine on hemodynamics and oxygen metabolism in hypoxic anesthetized piglets. Crit Care (2001) 5:158-68. doi:10.1186/cc1016

27. Eiby YA, Shrimpton NY, Wright IM, Lumbers ER, Colditz PB, Duncombe GJ, et al. Inotropes do not increase cardiac output or cerebral blood flow in preterm piglets. Pediatr Res (2016) 80:870-9. doi:10.1038/pr.2016.156

28. Eriksen VR. Rational use of dopamine in hypotensive newborns: improving our understanding of the effect on cerebral autoregulation. Dan Med J (2017) 64:B5388.

29. Noori S, Seri I. Neonatal blood pressure support: the use of inotropes, luisitropes, and other vasopressor agents. Clin Perinatol (2012) 39:221-38. doi:10.1016/j.clp.2011.12.010

30. Liet JM, Boscher C, Gras-Leguen C, Gournay V, Debillon T, Rozé JC. Dopamine effects on pulmonary artery pressure in hypotensive preterm infants with patent ductus arteriosus. J Pediatr (2002) 140:373-5. doi:10.1067/ mpd.2002.123100

31. Taketomo CK, Hodding JH, Kraus DM. Lexi-Comp's Pediatric Dosage Handbook. 12th ed. Hudson, OH: Lexi-Comp (2005). p. 446-7.

32. Seri I, Rudas G, Bors Z, Kanyicksa B, Tulassay T. Effects of low dose dopamine infusions in cardiovascular and renal functions, cerebral blood flow and plasma catecholamine levels in sick preterm neonates. Pediatr Res (1993) 34:742-9. doi:10.1203/00006450-199312000-00009

33. Padbury JF, Agata Y, Baylen BG, Ludlow JK, Polk DH, Goldblatt E, et al. Dopamine pharmacokinetics in critically ill newborn infants. J Pediatr (1987) 110:293-8. doi:10.1016/S0022-3476(87)80176-2

34. Sassano-Higgins S, Friedlich P, Seri I. A meta-analysis of dopamine use in hypotensive preterm infants: blood pressure and cerebral hemodynamics. J Perinatol (2011) 31:647-55. doi:10.1038/jp.2011.2

35. Bhayat SI, Gowda H, Eisenhut M. Should dopamine be the first line inotrope in the treatment of neonatal hypotension? Review of the evidence. World J Clin Pediatr (2016) 5:212-22. doi:10.5409/wjcp.v5.i2.212

36. Subhedar NV, Shaw NJ. Dopamine versus dobutamine for hypotensive preterm infants. Cochrane Database Syst Rev (2003) 3:CD001242. doi:10.1002/14651858.CD001242

37. Osborn D, Evans N, Kluckow M. Randomized trial of dobutamine versus dopamine in preterm infants with low systemic blood flow. J Pediatr (2002) 140:183-91. doi:10.1067/mpd.2002.120834

38. Eriksen VR, Rasmussen MB, Hahn GH, Greisen G. Dopamine therapy does not affect cerebral autoregulation during hypotension in newborn piglets. PLoS One (2017) 31:e0170738. doi:10.1371/journal.pone.0170738

39. Osborn DA, Evans N, Kluckow M. Left ventricular contractility in extremely premature infants in the first day and response to inotropes. Pediatr Res (2007) 61:335-40. doi:10.1203/pdr.0b013e318030d1e1

40. Ferrara JJ, Dyess DL, Peeples GL, Christenberry DP, Roberts WS, Tacchi EJ, et al. Effects of dopamine and dobutamine on regional blood flow distribution in the neonatal piglet. Ann Surg (1995) 221:531-42. doi:10.1097/00000658199505000-00011

41. Hentschel R, Hensel D, Brune T, Rabe H, Jorch G. Impact on blood pressure and intestinal perfusion of dobutamine or dopamine in hypotensive preterm infants. Biol Neonate (1995) 68:318-24. doi:10.1159/000244252

42. Gupta S, Donn SM. Neonatal hypotension: dopamine or dobutamine? Semin Fetal Neonatal Med (2014) 19:54-9. doi:10.1016/j.siny.2013.09.006

43. Robel-Tillig E, Knupfer M, Pulzer F, Vogtmann C. Cardiovascular impact of dobutamine in neonates with myocardial dysfunction. Early Hum Dev (2007) 83:307-12. doi:10.1016/j.earlhumdev.2006.06.005

44. Bravo MC, López-Ortego P, Sánchez L, Riera J, Madero R, Cabañas F, et al Randomized, placebo-controlled trial of dobutamine for low superior 
vena cava flow in infants. J Pediatr (2015) 167:572-8. doi:10.1016/j.jpeds. 2015.05.037

45. Rios DR, Moffett BS, Kaiser JR. Trends in pharmacotherapy for neonatal hypotension. J Pediatr (2014) 165:697-701. doi:10.1016/j.jpeds.2014.06.009

46. Slain KN, Shein SL, Rotta AT. The dose makes the poison: comparing epinephrine with dopamine in pediatric septic shock. Crit Care Med (2016) 44:e300. doi:10.1097/CCM.0000000000001542

47. Oualha M, Urien S, Spreux-Varoquaux O, Bordessoule A, D’Agostino I, Pouard P, et al. Pharmacokinetics, hemodynamic and metabolic effects of epinephrine to prevent post-operative low cardiac output syndrome in children. Crit Care (2014) 18:R23. doi:10.1186/cc13707

48. Caspi J, Coles JG, Benson LN, Herman SL, Diaz RJ, Augustine J, et al. Age related response to epinephrine induced myocardial stress. A functional and ultrastructural study. Circulation (1991) 84:III394-9.

49. Phillipos EZ, Robertson MA. A randomized double blinded trial of dopamine versus epinephrine for inotropic support in premature infants $<1750$ grams. Pediatr Res (2000) 47:425A.

50. Seri I, Evans J. Addition of epinephrine to dopamine increases blood pressure and urine output in critically ill extremely low birth weight neonates with uncompensated shock. Pediatr Res (1998) 43:194A. doi:10.1203/00006450199804001-01152

51. Pellicer A, Valverde E, Elorza MD, Madero R, Gayá F, Quero J, et al. Cardiovascular support for low birth weight infants and cerebral hemodynamics: a randomized, blinded clinical trial. Pediatrics (2005) 115:1501-12. doi:10.1542/peds.2004-1396

52. Valverde E, Pellicer A, Madero R, Elorza D, Quero J, Cabañas F. Dopamine versus epinephrine for cardiovascular support in low birth weight infants: analysis of systemic effects and neonatal clinical outcomes. Pediatrics (2006) 117:1213-22. doi:10.1542/peds.2005-2108

53. Paradisis M, Osborn DA. Adrenaline for the prevention of morbidity and mortality in preterm infants with cardiovascular compromise. Cochrane Database Syst Rev (2004) 1:CD003958. doi:10.1002/14651858.CD003958.pub2

54. Seri I. Circulatory support of the sick preterm infant. Semin Neonatol (2001) 6:85-95. doi:10.1053/siny.2000.0034

55. Tourneux P, Rakza T, Bouissou A, Krim G, Storme L. Pulmonary circulatory effects of norepinephrine in newborn infants with persistent pulmonary hypertension. J Pediatr (2008) 153:345-9. doi:10.1016/j.jpeds.2008.03.007

56. Cutaia M, Friedrich P. Hypoxia-induced alterations of norepinephrine vascular reactivity in isolated perfused cat lung. J Appl Physiol (1987) 63:982-7. doi:10.1152/jappl.1987.63.3.982

57. Tulloh RM, Dyamenahalli U, Stuart-Smith K, Haworth SG. Adrenoceptorstimulated endothelium-dependent relaxation in porcine intrapulmonary arteries. Pulm Pharmacol (1994) 7:299-303. doi:10.1006/pulp.1994.1035

58. Tourneux P, Rakza T, Abazine A, Krim G, Storme L. Noradrenaline for management of septic shock refractory to fluid loading and dopamine or dobutamine in full-term newborn infants. Acta Paediatr (2008) 97:177-80. doi:10.1111/j.1651-2227.2007.00601.x

59. Oualha M, Tréluyer JM, Lesage F, de Saint Blanquat L, Dupic L, Hubert P, et al. Population pharmacokinetics and haemodynamic effects of norepinephrine in hypotensive critically ill children. Br J Clin Pharmacol (2014) 78:886-97. doi:10.1111/bcp.12412

60. Rowcliff K, de Waal K, Mohamed A-L, Chaudhari T. Noradrenaline in preterm infants with cardiovascular compromise. Eur J Pediatr (2016) 175:1967-73. doi:10.1007/s00431-016-2794-7

61. Rizk MY, Lapointe A, Lefebvre F, Barrington KJ. Norepinephrine infusion improves haemodynamics in the preterm infants during septic shock. Acta Paediatr (2018) 107:408-13. doi:10.1111/apa.14112

62. Schwartz S. In: Redington AN, et al., editors. Acute Right Ventricular Failure. Congenital Diseases of the Right Heart. London: Springer-Verlag Publishers (2009). p. 213-8.

63. Meyer S, Gottschling S, Baghai A, Wurm D, Gortner L. Arginine-vasopressin in catecholamine-refractory septic versus non-septic shock in extremely low birth weight infants with acute renal injury. Crit Care (2006) 10:R71-6. doi:10.1186/cc4917

64. Meyer S, Loffler G, Polcher T, Gottschling S, Gortner L. Vasopressin in catecholamine-resistant septic and cardiogenic shock in very-low-birthweight infants. Acta Paediatr (2006) 95:1309-12. doi:10.1080/08035250500 538973
65. Lechner E, Hofer A, Mair R, Moosbauer W, Sames-Dolzer E, Tulzer G. Arginine-vasopressin in neonates with vasodilatory shock after cardiopulmonary bypass. Eur J Pediatr (2007) 166:1221-7. doi:10.1007/s00431-006-0400-0

66. Bidegain M, Greenberg R, Simmons C, Dang C, Cotten CM, Smith PB. Vasopressin for refractory hypotension in extremely low birth weight infants. J Pediatr (2010) 157:502-4. doi:10.1016/j.jpeds.2010.04.038

67. Alten JA, Borasino S, Toms R, Law MA, Moellinger A, Dabal RJ. Early initiation of arginine vasopressin infusion in neonates after complex cardiac surgery. Pediatr Crit Care Med (2012) 13:300-4. doi:10.1097/PCC.0b013e31822f1753

68. Holmes CL, Patel BM, Russell JA, Walley KR. Physiology of vasopressin relevant to management of septic shock. Chest (2001) 120:989-1002. doi:10.1378/ chest.120.3.989

69. Treschan TA, Jurgen P. The vasopressin system: physiology and clinical strategies. Anesthesiology (2006) 105:599-612. doi:10.1097/00000542-200609000-00026

70. Dyke PC II, Tobias JD. Vasopressin: applications in clinical practice. J Intensive Care Med (2004) 19:220-8. doi:10.1177/0885066604265246

71. Tamaki T, Kiyomoto K, He H, Tomohiro A, Nishiyama A, Aki Y, et al. Vasodilation induced by vasopressin V2 receptor stimulation in afferent arterioles. Kidney Int (1996) 49:722-9. doi:10.1038/ki.1996.101

72. Evora PR, Pearson PJ, Schaff HV. Arginine vasopressin induces endotheliumdependent vasodilatation of the pulmonary artery. V1-receptor-mediated production of nitric oxide. Chest (1993) 103:1241-5. doi:10.1378/chest.103. 4.1241

73. Jin HK, Chen YF, Yang RH, McKenna TM, Jackson RM, Oparil S. Vasopressin lowers pulmonary artery pressure in hypoxic rats by releasing atrial natriuretic peptide. Am JMed Sci (1989) 298:227-36. doi:10.1097/00000441-198910000-00004

74. Walker BR, Haynes J Jr, Wang HL, Voelkel NF. Vasopressin-induced pulmonary vasodilation in rats. Am J Physiol (1989) 257:H415-22.

75. Landry DW, Oliver JA. The pathogenesis of vasodilatory shock. N Engl J Med (2001) 345:588-95. doi:10.1056/NEJMra002709

76. Barrett LK, Singer M, Clapp LH. Vasopressin: mechanisms of action on the vasculature in health and in septic shock. Crit Care Med (2007) 35:33-40. doi:10.1097/01.CCM.0000251127.45385.CD

77. Masarwa R, Paret G, Perlman A, Reif S, Raccah B, Matok I. Role of vasopressin and terlipressin in refractory shock compared to conventional therapy in the neonatal and pediatric population: a systematic review, meta-analysis, and trial sequential analysis. Crit Care (2017) 21:1. doi:10.1186/s13054-016-1589-6

78. Rios D, Kaiser JR. Vasopressin versus dopamine for treatment of hypotension in extremely low birth weight infants: a randomized, blinded pilot study. J Pediatr (2015) 166:850-5. doi:10.1016/j.jpeds.2014.12.027

79. Ikegami H, Funato $M$, Tamai $H$, Wada H, Nabetani M, Nishihara M. Low-dose vasopressin infusion therapy for refractory hypotension in ELBW infants. Pediatr Int (2010) 52:368-73. doi:10.1111/j.1442-200X.2009.02967.x

80. Acker S, Kinsella JP, Abman S, Gien J. Vasopressin improves hemodynamic status in infants with congenital diaphragmatic hernia. J Pediatr (2014) 165:53-8. doi:10.1016/j.jpeds.2014.03.059

81. Ni M, Kaiser JR, Moffett BS, Rhee CJ, Placencia J, Dinh KL, et al. Use of vasopressin in neonatal intensive care unit patients with hypotension. J Pediatr Pharmacol Ther (2017) 22:430-5. doi:10.5863/1551-6776-22.6.430

82. Cornette L, Levene MI. Post resuscitative management of the asphyxiated term and preterm infant. Semin Neonatol (2001) 6:271-82. doi:10.1053/siny. 2001.0055

83. Lakshminrusimha S, Konduri GG, Steinhorn RH. Considerations in the management of hypoxemic respiratory failure and persistent pulmonary hypertension in term and late preterm neonates. J Perinatol (2016) 36:S12-9. doi:10.1038/jp.2016.44

84. Chang AC, Atz AM, Wernovsky G, Burke RP, Wessel DL. Milrinone: systemic and pulmonary hemodynamic effects in neonates after cardiac surgery. Crit Care Med (1995) 23:1907-24. doi:10.1097/00003246-199511000-00018

85. Hoffman TM, Wernovsky G, Atz AM, Kulik TJ, Nelson DP, Chang AC, et al. Efficacy and safety of milrinone in preventing low cardiac output syndrome in infants and children after corrective surgery for congenital heart disease. Circulation (2003) 107:996-1002. doi:10.1161/01.CIR.0000051365. 81920.28

86. Bassler D, Choong K, McNamara P, Kirpalani H. Neonatal persistent pulmonary hypertension treated with milrinone: four case reports. Biol Neonate (2006) 89:1-5. doi:10.1159/000088192 
87. Danhaive O, Margossian R, Geva T, Kourembanas S. Pulmonary hypertension and right ventricular dysfunction in growth restricted, extremely low birth weight neonates. J Perinatol (2005) 25:495-9. doi:10.1038/sj.jp.7211299

88. Bianchi MO, Cheung PY, Phillipos E, Aranha-Netto A, Joynt C. The effect of milrinone on splanchnic and cerebral perfusion in infants with congenital heart disease prior to surgery: an observational study. Shock (2015) 44:115-20. doi:10.1097/SHK.0000000000000388

89. Vogt W, Läer S. Prevention for pediatric low cardiac output syndrome: results from the European survey EuLoCOS-Paed. Paediatr Anaesth (2011) 21:1176-84. doi:10.1111/j.1460-9592.2011.03683.x

90. Samiee-Zafarghandy S, Raman SR, van den Anker JN, McHutchison K, Hornik CP, Clark RH, et al. Safety of milrinone use in neonatal intensive care units. Early Hum Dev (2015) 91:31-5. doi:10.1016/j.earlhumdev. 2014.10.007

91. James AT, Beel C, Corcoran JD, McNamara PJ, Franklin O, El-Khuffash AF. Treatment of premature infants with pulmonary hypertension and right ventricular dysfunction with milrinone: a case series. JPerinatol (2015) 35:268-73. doi:10.1038/jp.2014.208

92. Paradisis M, Evan N, Kluckow M, Osborn D. Randomized trial of milrinone versus placebo for prevention of low systemic blood flow in very preterm infants. JPediatr (2009) 154:189-95. doi:10.1016/j.jpeds.2008. 07.059

93. Sehgal A, Francis JV, Lewis AI. Use of milrinone in the management of haemodynamic instability following duct ligation. Eur J Pediatr (2011) 170:115-9. doi:10.1007/s00431-010-1296-2

94. Jain A, Sahni M, El-Khuffash A, Khadawardi E, Sehgal A, McNamara PJ. Use of targeted neonatal echocardiography to prevent postoperative cardiorespiratory instability after patent ductus arteriosus ligation. J Pediatr (2012) 160:584-9. doi:10.1016/j.jpeds.2011.09.027

95. Halliday M, Kavarana M, Ebeling M, Kiger J. Milrinone use for hemodynamic instability in patent ductus arteriosus ligation. J Matern Fetal Neonatal Med (2017) 30:529-33. doi:10.1080/14767058.2016.1177720

96. Akita T, Joyner RW, Lu C, Kumar R, Hartzell HC. Developmental changes in modulation of calcium currents of rabbit ventricular cells by phosphodiesterase inhibitors. Circulation (1994) 90:469-78. doi:10.1161/01. CIR.90.1.469

97. McNamara PJ, Shivananda SP, Sahni M, Freeman D, Taddio A. Pediatric pharmacology of milrinone in neonates with persistent pulmonary hypertension of the newborn and suboptimal response to inhaled nitric oxide. Crit Care Med (2013) 14:74-84. doi:10.1097/PCC.0b013e31824ea2cd

98. Zuppa AF, Nicolson SC, Adamson PC, Wernovsky G, Mondick JT, Burnham N, et al. Population pharmacokinetics of milrinone in neonates with hypoplastic left heart syndrome undergoing stage I reconstruction. Anesth Analg (2006) 102:1062-9. doi:10.1213/01.ane.0000198626.67391.34

99. Giaccone A, Zuppa AF, Sood B, Cohen MS, O’Byrne ML, Moorthy G, et al. Milrinone pharmacokinetics and pharmacodynamics in neonates with persistent pulmonary hypertension of the newborn. Am J Perinatol (2017) 34:749-58. doi:10.1055/s-0036-1597996

100. Mertens L, Seri I, Marek J, Arlettaz R, Barker P, McNamara P, et al. Targeted neonatal echocardiography in the neonatal intensive care unit: practice guidelines and recommendations for training. Eur J Echocardiography (2011) 12:715-36. doi:10.1093/ejechocard/jer181

101. Dix LM, van Bel F, Lemmers PM. Monitoring cerebral oxygenation in neonates: an update. Front Pediatr (2017) 5:46. doi:10.3389/fped.2017.00046

102. Kluckow M, Evans N. Relationship between blood pressure and cardiac output in preterm infants requiring mechanical ventilation. J Pediatr (1996) 129:506-12. doi:10.1016/S0022-3476(96)70114-2

Conflict of Interest Statement: The authors declare that the research was conducted in the absence of any commercial or financial relationships that could be construed as a potential conflict of interest.

Copyright (C) 2018 Joynt and Cheung. This is an open-access article distributed under the terms of the Creative Commons Attribution License (CC BY). The use, distribution or reproduction in other forums is permitted, provided the original author(s) and the copyright owner are credited and that the original publication in this journal is cited, in accordance with accepted academic practice. No use, distribution or reproduction is permitted which does not comply with these terms. 